\title{
NINGYO LEGENDS, ENSHRINED ISLANDS AND THE ANIMATION OF AN AQUAPELAGIC ASSEMBLAGE AROUND BIWAKO
}

[Received April 27th 2018; accepted August 1oth 2018 - DOI: 10.21463/shima.12.2.08]

$$
\text { Juni'chiro Suwa }
$$

Hirosaki University <suwa@hirosaki-u.ac.jp>

\begin{abstract}
Biwako is the largest lake in Japan. Its waters, islands and shores have a rich mythology due, in substantial part, to their close proximity to the ancient cities of Kyoto and Nara. This article focuses on two interlinked aspects of the region's aquatic legends. The first concerns the presence of ningyo (folkloric fish-bodied and human headed creatures credited with human-like intelligence) around the eastern part of the lake and their interaction with human communities. In several accounts, the ningyo were caught and killed by local villagers and a number of temples have subsequently claimed to hold the mummified bodies of these creatures. Nihonshoki, an imperial chronicle from the 1720 S CE, tells of a ningyo that appeared as an omen of the death of a prince and folklore relates that the same prince enshrined a mummified ningyo in a local temple before his demise. In this manner, the prince, the legendary ningyo, the preserved ningyo, local villagers and the region's enshrining religious institutions are intertwined within the aquatic system of Biwako. Secondly, the lake is known for centuries-old sanctuary islands on which Buddhist temples and Shinto shrines have been built. These contain sacred statues and talismans and indicate the manner in which the entire domain of individual islands is an object of worship. The (supposedly preserved) ningyo artefacts of shoreline and inland temples and the enshrined islands manifest and animate the overall aquapelagic assembly of the region. I use the word "animate" to express the manner in which local ningyo legends and sacred island spaces are experienced as "real". The preserved ningyo artefacts and islands are animated in the spatialconceptual context of the lake as the materiality of its water generates a whole territory of mythical and contemporary landscapes.
\end{abstract}

KEYWORDS: Ningyo, ningyo no miira, Biwako, aquapelagic assemblage, sanctuary island

Introduction

Biwako, the largest lake in Japan, is located in the centre of Shiga Prefecture (Figure 1). ${ }^{1}$ The lake derives its name from its shape, which resembles that of the biwa (lute), an aspect that reflects the lake's symbolic association with the medieval goddess Benzaiten, who is the guardian of commerce, marine traffic, fisheries, music and the performing arts. As she is also identified with Shinto island goddesses, she is often enshrined on islands and her shrines' iconographies traditionally represent her holding the lute (Suwa, 2017). There are a number of legends regarding ningyo ${ }^{2}$ (fish-bodied and human headed creatures credited

\footnotetext{
${ }^{1}$ See Kawanabe, Nishino and Maehata (eds) (2012) for a detailed study of the interactions between humans and the natural world in and around the lake.

${ }^{2}$ Traditionally the word ningyo is not considered to specify a particular gender. As per standard Japanese language usage, it is both singular and plural, the latter aspect being determined by context.
}

Shima <www.shimajournal.org> ISSN: 1834-6057 
with human-like intelligence) around the lake and related rivers. Similarly, there are also a number of artefacts regarded as mummified ningyo that are, actually, fabricated artefacts created for commercial purposes in Japan during the $170 \mathrm{os}-1800$ s. $^{3}$ These artefacts, commonly and henceforth referred to as ningyo no miira, are preserved as sacred treasures in Buddhist temples around Shiga in sealed containers where their form is hidden from public gaze (and/or scrutiny). In an attempt to expand the idea of island space, this article discusses the folklore associated with ningyo, ningyo no miira and the religious folklore associated with Chikubushima, a small island sanctuary located in the far north of Biwako (Figure 1). The two phenomena-singly and in combination-can be perceived as a type of aquapelagic assemblage. This type is one that goes beyond the term's initial conceptualisation as an integrated terrestrial and marine space (Hayward, 2012) constituted by livelihood activities (Suwa, 2012) and-like the case of the Bentensai of Sakurajima (see Suwa, 2016)-is an articulation of liquid and material spaces enabled by symbolic objects and rituals. The waters and islands of the lake are thereby indispensable repositories and generators of ideas, legends and beliefs that enable objects to be kept in structures located within and around the lake in order that sanctuaries can be maintained in their vicinities. As a consequence, the waters become sacred as territory, a shima, in their own right.

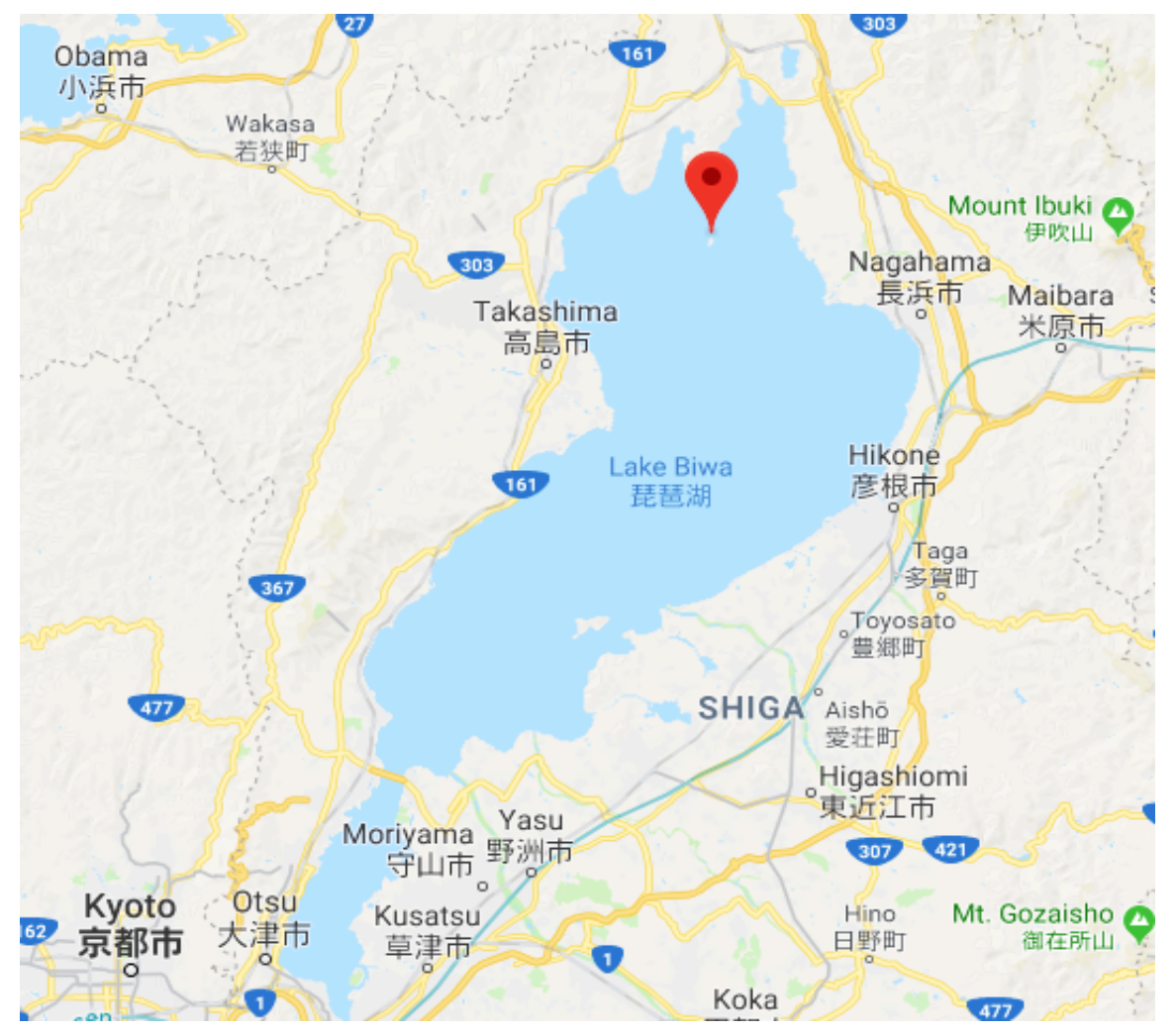

Figure 1 - Lake Biwa and surrounding shores, with Chikubushima identified with a red pin (Google Maps image, 2017).

\footnotetext{
${ }^{3}$ These were assembled from the bodies of fishes, and often with a monkey's head, public display as supposedly authentic, preserved yokai (folkloric creatures of various kinds).
}

\section{Shima Volume 12 Number 22018


The following discussions revisit Alfred Gell's Art and Agency (1998). This posthumous work is, in many parts, incomplete but still presents dazzling ideas, in particular, the author's outline of the interaction of agency in artistic objects. With graphic examples from Polynesian religious wood carving traditions, Gell illustrates that any artistic or religious object is intracorporeally embedded in experience as well as belief or intuition. Gell developed the esthetical faculty into a social plane-agency-which this article values greatly. Agency can be seen as a sensibility with a societal dimension; it is a modus vivendi in that a car, for instance, not only reflects the owner's personhood but has its own "personhood" as a car (Gell, 1998: 18-19). Viewed in this manner, the Biwako ningyo no miira can be regarded as agents of the lake that contribute to local aquapelagic assemblage(s). The lake can exist as a socio-cultural entity if it is sensed in the experience of encountering the ningyo no miira. Similarly, Chikubushima can also be regarded as an agent of Biwako because the sacred status of the lake's waters sanctuarises it, rendering the island as sacred and enshrined in its own right. The modus vivendi of agency, understood in this sense, will henceforth be referred to as an "animation".

In my previous articles in this journal, I have discussed case studies from northern Japan and Amami with a particular focus on territoriality of the specific type termed as shima in Japan and the Ryukyu Islands (Suwa, 2007; 2012; 2017). This article aims to explicate that any understanding of an aquapelagic assemblage as a shima necessarily involves the substance of the water as well as its more abstract space. In other words, the reality of shima is substantive in that it generates and is generated by material objects, with this interaction germinating what might be considered as a cultural "seed". In the case of Biwako, the ningyo no miira and Chikubushima (as a sanctuary of Benzaiten) are the substance of a shimatic aquapelagic assemblage at the same time as they are extracted from the same milieu (ie Biwako). They can contain as the sacred or become a sanctuary since they are generated by the waters that animate their socio-cultural activity. Biwako's aquatic system manifests as an aquapelagic assemblage by virtue of the substance of its waters and their perception/retention as sacred. Biwako's aquapelagic assemblage will now be discussed in terms of the mutual interaction that generates a connective web involving ningyo no miira, Chikubushima and the personhoods of historical figures.

\section{Biwako's Waters as an Agent}

Drawing on the development of the concept in Linguistics (see Ahern, 2001), "agency" can be understood as involving an interaction between the agent, who initiates an action or process of signification, and the patient, who is the recipient of an action or process of signification. Dependent on the type of interaction between the two, a complex matrix of semiosis can develop (Gell, 1998: 29-65). However, the mere recognition of this does not, in itself, produce a productive analytical framework. Indeed, the simple identification of the agent and patient of agency omits consideration of how exactly how the two interact in any event. In fact, conceived of at the passive end of action networking, the concept is somewhat redundant because the "passive" side also influences the other party; therefore, the two might be more accurately be regarded as agents to each other. In an anthropological context, the application of this model to the Marquesan carvings discussed by Gell, for instance, could not properly explain their presence and modus vivandi without the operation of magical power. This points to the manner in which the agency of artefacts is enacted in a magical way to produce their presence and operation in the Marquesan world. As Gell points out, such artefacts are "shaped in the 'inter-artefactual domain', obeying the immanent injunctions governing formal stylistic relationships among artefacts” (ibid: 216).

Shima Volume 12 Number 22018 
Gell's idea of agency is linked to arguments made by Taussig (1993) concerning the contingent power of sorcery, ${ }^{4}$ as well to Benjamin's explications on copying and mimesis, or "mimetic faculty" (1979). Taking the example of Euro-American Cuna figurines as a form of sorcery (1993: 8), Taussig argues that the mimetic faculty is a sensory organisation that connects the object of magic and the sorcerer through magical contact between them. In replacing the idea of mimetic faculty, which tends to be entangled with unfruitful considerations of the dichotomy of the original versus the copy, Gell proposes the concept of agency, with particular regard to causality, in the following terms:

Magic is possible because intentions cause events to happen in the vicinity of agents, but this is a different species of causation from the kind of causation involved in... the falling of Newton's apple etc. (1988: 101).

Gell further develops the idea of "magical contact" as a "causal arrow between desire and accomplishment" and gives the example of boiled eggs:

If there were no breakfast-desiring agents like me about, there was no hen's eggs (except in South-East Asian jungle), no saucepans, no gas appliances, and the whole egg-boiling phenomenon would never transpire and never need to be physically explained. So, whatever the verdict of physics, the real causal explanation for why there are any boiled eggs is that I, and other breakfasters, intend that boiled eggs should exist. (ibid)

From this perspective, magic is a category of causality that never requires essentialism. For instance, there is no essential difference between Melanesian cargo cults and the boiling of an egg for English breakfast, inasmuch as the phenomena are intended as events staged in the vicinity of agents. A cargo cult's actions could be identified as deficient, in that simply building a hut and calling it a "bank" or "post office" does not produce the result initially intended (such as receiving cargo or remittances from a superhuman entity). It is not a matter of how the action appears to involve the supernatural or how it is described in terms of its ineffectuality. Instead, the bottom line of magical causality is that intention, often expressed as a performative action, makes the event of agency real.

In the case of Biwako, it is causality and intention in the vicinity of events-ie the (supposed) mummification of ningyo as well as the territorialisation of island sanctuaries-that is most significant. As will be discussed in detail, the fundamental question concerns exactly how the "vicinity of event", which enables the modus vivendi of representative operations, becomes substantive in social interactions. In other words, the question of how agency generates space by effectual interaction becomes the foremost concern. Gell states that the "kind of agency exercised in the vicinity of work of art varies considerably, depending on a number of contextual factors" (ibid: 66). If one can define a "work of art" in a broad sense, this passage gives some room for interpretation. "Art" can involve any magical causality, such as the boiled eggs in Gell's parable; indeed, we can regard a boiled egg as a work of art if necessary. Consequently, in this article the concept of the "work of art" is extended to the creation of ningyo no miira as well as the sacred being enshrined.

The modus vivendi of agency can involve a particular kind of communal enterprise that Gell calls a "cult of images" (ibid: 106-109). Such a "cult" is inculcated through ritual activity or

${ }^{4}$ A concept originally proposed by Frazer (1976 [1911]).

Shima Volume 12 Number 22018

- 69 - 
sorcery and this is the reason that many idols are anthropomorphic figures and/or are believed to represent the body of a cosmological entity such as an invisible god. Gell further discusses the work of art in terms of what he calls the "distribution of personhood" and "fractal personhood" (ibid: 98-154). In order for an idol to interact magically it has to be animated, and a cult of images manifests itself as the space of that animation. In the case of the medieval Christian vierge ouverante icons (Figure 2 ), ${ }^{5}$ for example, the animation of an idol is accomplished by fractal images of its body and face, in that the hollow statue of the Virgin Mary contains a model of Jesus and the crucifix within it. By the same token, the Polynesian A'a deity from Ruruta is represented by an idol with a fractal aspect, with many small faces sprouting all over from its body. The magical interaction involves distributing the personhood of those who are involved in the interaction, either imagined or real, and animating the personhood in a fractal manner. Although the religious artefacts and curios from Biwako show no obvious signs of bodies containing other bodies, or sprouting heads, the personhood of sacred beings, as well as ningyo, are distributed so that their shrines and monuments are constructed in a fractal manner, in a territorialisation of/as shima.

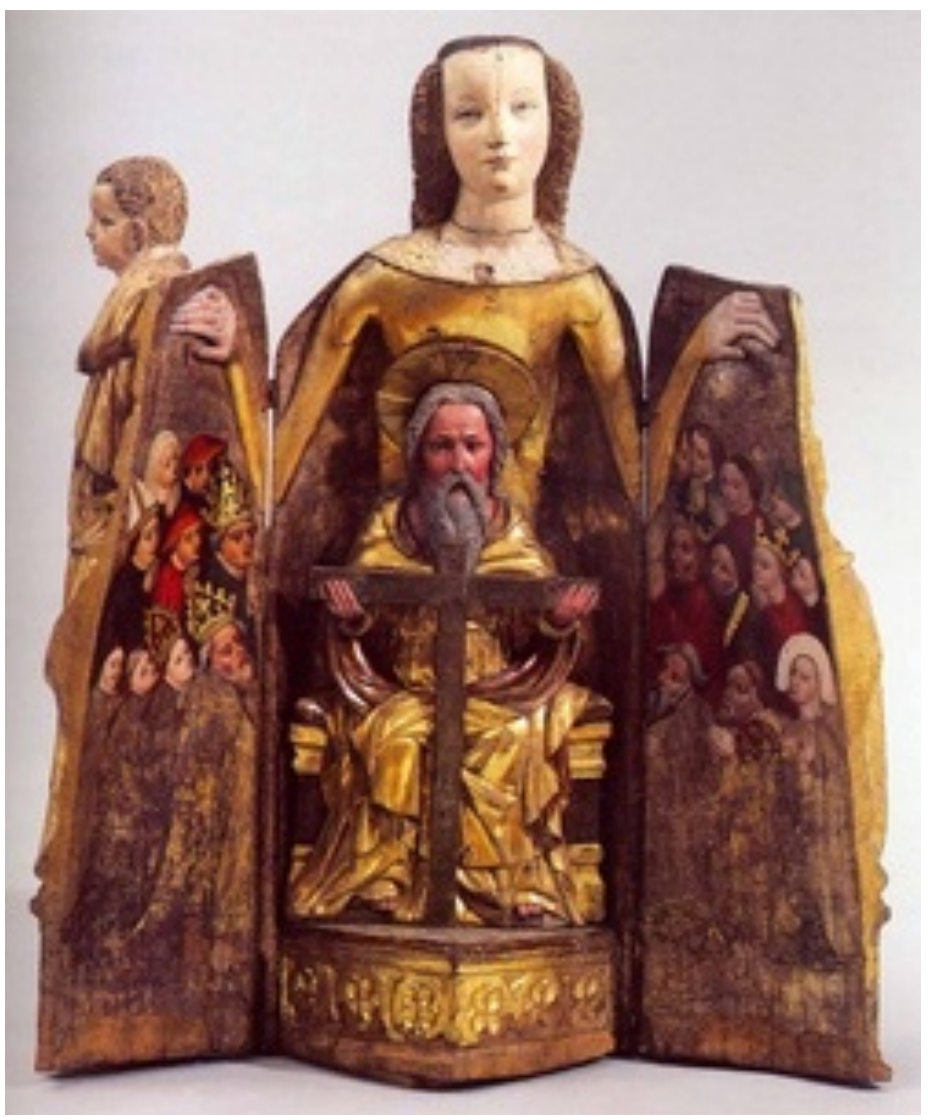

Figure 2 - A 15th Century German vierge ouvrante (photographer unknown).

\footnotetext{
${ }^{5}$ Literally "opening virgins" - icons of the Virgin Mary that open to present a tableau of the Holy Trinity.
}

\section{Shima Volume 12 Number 22018}


The waters of Biwako serve as an agent for animating otherwise isolated items into an aquapelagic assemblage by embedding them into a singular space of territoriality. In an aquapelagic assemblage, water is not simply a fluid body that comprises a blank space but is, rather, an agent that animates the territories of works of art. The aquapelagic assemblage is a system in which the animation of magical agents takes place in the vicinity of water, or, otherwise, water attains agency by itself. In this manner, waters can be considered as events and as territories by nature. Whereas ningyo no miira and the enshrined bodies of other sacred beings distribute their personhood in their vicinity-the shrines and temples are identified with them, the legends that become contingent to local identity, and so on-waters animate their personhood within an aquapelagic system. The waters are an agent to ningyo no miira, and to Chikubushima's status as an island sanctuary, because they surround and envelop the latter. As will be discussed in detail later in the article-the legends characterise the waters as an indispensable substance that generates the space of mythical reality. The waters of Biwako animate the "becoming" of the enshrined Benzaiten as well as the apparently half-human entities carefully showcased for the tourists and pilgrims who visit magical "power spots" around Biwako's coast and hinterland. The waters of Biwako contain, encompass and maintain the temples and island sanctuaries that store the sacred bodies and that make the cult of their image a reality. Therefore, the waters are an agent to intention that materialises the mythical reality of the artefacts and organises them as a fractal space.

Ningyo interact with a reality in which local livelihood is embedded in the landscape abutting the lakespace that generates its communities' livelihood and, thereby, raisons d'etre. Here, if we consider the ningyo as an allegory of water and land, such a becoming would be a manifestation of what Hayward describes as an "aquapelagic imaginary" (2017: 4). As he discusses, this concerns the manner in which mermaids, mermen, ningyo or other entities can be considered as manifestations of a worldview and imagination that "explores the boundaries between marine and terrestrial worlds and experiences in various ways" (ibid: 4-5).

The aquapelagic imaginary can be seen to generate magical relationships, among which are those related to the assemblage of water with land, and enables desires for contacts to be realised in the vicinity of water. In terms of the latter, the subjectivity of the aquapelagic imaginary should actually be grasped as intersubjective because the aspects and entities connected by (or embedded within) aquapelagic territoriality envelop whatever and whoever is involved in the process of imagination. The aquapelagic imaginary, then, is a way of imagining and sensing the world; or else, a sensibility that essentially generates the reality to be. Nonetheless, it has to be emphasised that ningyo and, in particular, those materialised as mummified artefacts, are not the mere end product of the aquapelagic imaginary. In fact, the latter provides the pre-condition of the aquapelagic assemblage, just as Gell characterises that, "whatever the verdict of physics, the real causal explanation for why there are any boiled eggs is that I, and other breakfasters, intend that boiled eggs should exist" (1998: 101). A ningyo might not form an aquapelagic assemblage by itself, as long as it is regarded as a passive, un-answering "patient", to use Gell's terminology; however, it can become an assemblage through a process in which interrelation in the vicinity of a ningyo's body (true, imagined and/or mummified) articulates the reality of the ningyo. Legends, historical architectures, religion and the livelihood of the waterside fishery all embed the ningyo into a space that is generated as an assemblage. One aspect of the aquapelagic assemblage of Biwako is thereby generated by the ningyo's corporeality within a lacustrine locale. The space of/with the ningyo becomes an aquapelagic assemblage as a particular substantive space (or a distinct territoriality) that articulates water and land, making the

Shima Volume 12 Number 22018

-71 - 
livelihood of Biwako inseparable from its body of waters. The aquapelagic assemblage of Biwako thereby entails the ningyo and its vicinity being inclusive, transforming a space of shima where the agency of ningyo and human exist in singular territoriality.

\section{Biwako’s Ningyo No Miira}

The large flatland, rich soil and abundant water of Biwako's hinterland have long attracted rice farmers to the region and both subsistence and commercial fisheries, harvesting fish, shellfish and shrimps, have prospered in the lake since the early medieval period (1185-1333 CE). Merchants have also used the lake to transport rice, fish and other local products to major commercial and government centres such as Kyoto and Nara. Due to the large body of consumers in Kyoto and other population centres and the small-scale, artisanal nature of early fisheries, the lake was envisaged and exploited as a commons - conforming to the Buddhist creed that discourages excessive/unsustainable killing of fish (Hashimoto, 2012). The imperial chronicle Nihonshoki relates that Emperor Tenji, then a prince, relocated his capital from Asuka (south of Nara) to Ötsu (on the south-western shore of Biwako) in 667 CE. While the chronicle does not give any explanation for Tenji's move, it was so unpopular that Asuka residents criticised and resisted the imperial decree, deriding it in children's songs and staging numerous incidents of arson. Eventually the Ōtsu palace was abandoned and the royal court moved back to Asuka only five years later. Despite this abortive move, the Biwako area has continued to attract political leaders ever since and a number of religious centres have also been founded in the area.

The Nihonshoki also includes accounts of a ningyo spotted in Osaka Bay in 619 CE. Subsequently a fisherman in the north of (present-day) Osaka prefecture (an area connected with Biwako by the Ujigawa and Ydodgawa rivers) reportedly caught a half-human, half-fish creature the size of a small child in his net. Paranormal and grotesque things were interpreted as auspicious omens in ancient Japan and reference to such strange things in chronicles served to dramatise political events. The appearance of the ningyo might, for instance, have been interpreted as premonitions of the death of Prince Umayado (also known as Shōtoku-taishi, "the prince of sacred virtue") that followed in 621 CE. To the editors of Nihonshoki, the death of Umayado was symbolic of the end of the political order of the ancient state system; therefore, the records of occult incidents were probably inserted to serve as signs of the times.

Prince Umayado also appears in a local ningyo legend that concerns the ningyo no miira enshrined in Ganjōji Temple, located close to Gamō village in the south-western hinterland of the lake (Figure 3). The temple is said to have been founded by Umayado in 619 CE (Sōtōsōmuchō, 2018) - the same year that the ningyo referred to above were spotted around the area of Biwako-Osaka Bay. There are no official historical accounts but a number of local legends relate that Prince Umayado ordered a ningyo no miira-possibly the corpse of the one caught near Osaka in the previous year-to be enshrined in the Ganjōji Temple shortly before his demise (Igarashi, 2017). While there is no authoritative verification of the identity/provenance of the ningyo no miira-or of Umayado's role in establishing the templethe local cultural imagination embedded in legends and temples clearly reflects the aforementioned passages in Nihonshoki that offer an assemblage of the lake, the dead prince and ningyo. 


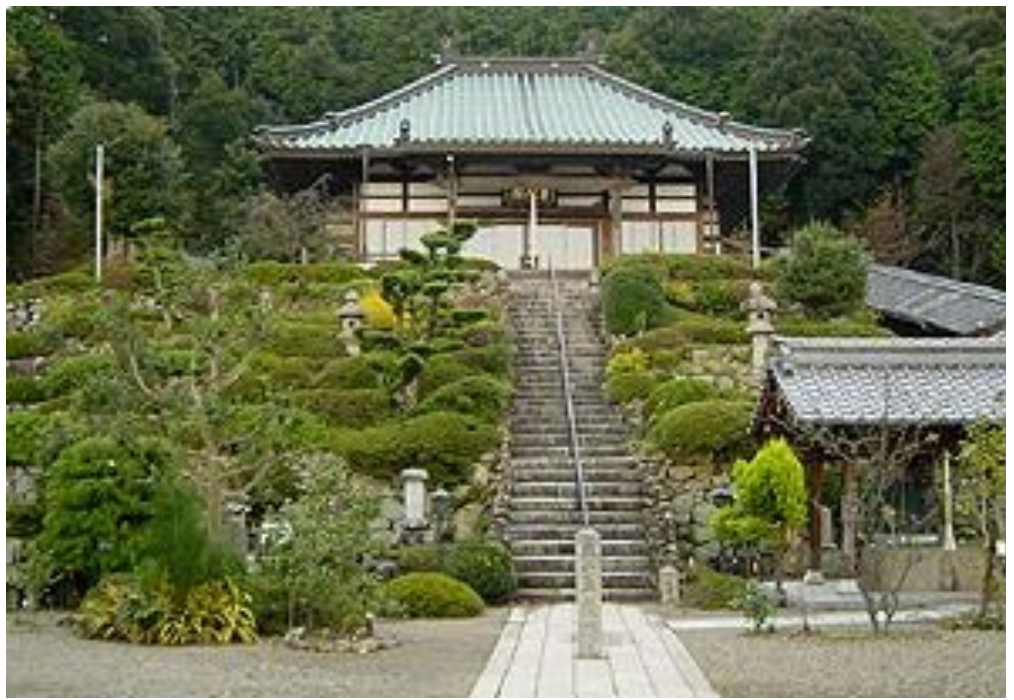

Figure 3 - Ganjōji temple near Gamō (source Nippon Kichi, 2008: online)

Another local legend describes a ningyo who masqueraded as a young human male (presumably altering his body to do so):

There was a beautiful nun in Ganjöji. One day, a handsome boy came to the temple to serve the nun, and he soon began to make regular visits to her. Mysteriously, however, nobody knew where the boy was from. Since the villagers were jealous of the boy they started to search for his identity. A man followed the boy from the temple and saw him disappear into a pool in Sakura River. On the next day, villagers scoured the pool and caught a ningyo in fishing net. It was this ningyo who had disguised himself as the handsome young boy and approached the nun. The villagers instantly killed the creature in anger for it showing affection for the nun and for trying to seduce her. The body of the ningyo was then mummified and exhibited as a spectacle around Japan before being sold to a private collector. However, the ningyo no miira wailed in the night and was eventually brought back to Ganjōji, where the nun's tomb is, for a kuyō (memorial service). (Igarashi, 2017: online - author's translation)

Other accounts tell of three ningyo that lived in a local river:

When a severe drought struck this area, villagers scooped water from Gamō River with buckets to maintain their fields. One pool by the river, named Koshōgafuchi, never became empty. As the water was bucketed out it filled up by itself. The villagers wondered how this happened but simply gave thanks for the miracle.

One day a young man went to the pool in the dark to investigate the mystery. He recognised three figures in the river who were servants who worked for the nun in Kannondō, a hamlet near the pool but, on closer inspection, he perceived that the three were not human and were scooping up water from the river with their fins to fill up the pool. The terrified villager kept silent about what he saw

\section{Shima Volume 12 Number 22018}


but the rumour soon spread. Eventually, one of the monsters was later caught in a fishing net and was found to be a ningyo.

The body of the ningyo was subsequently mummified and circulated as a curio. However, each successive owner was cursed and the ningyo no miira was finally stored in Ganjōii, where it rests today. Another ningyo was found in the river running through Hino Village and was killed by villagers and buried in a mound. The last one was taken by the saintly monk Kükai, with its body being mummified in order to be stored in Kamuro Karukayadō, on Mount Kōya, where Kūkai founded a centre of esoteric Buddhism. (Nihon Denshō Taikan Seisaku Ĩnkai, 2017: online - author's translation)

Kannonshōji Temple, located between Gamō and Biwako, used to keep a ningyo no miira that was burned in a fire in 1993. The legend behind this relates to Prince Umayado:

When Prince Umayado was travelling around Ōmi he happened to meet a ningyo that came up from Biwako and spoke to the prince. It begged for mercy saying: "I was a fisherman but the karma reincarnated me into such an ugly creature as this. I did not respect the Buddha's law and idly slaughtered life in the water. And now, lots of fish attack me, sucking my blood with no rest. How painful it is! Please help me!" Umayado felt pity for the fisherman. He carved a statue of Senju Kannon ${ }^{6}$ and enshrined it in a temple on Kinugasayama Mountain, which he built, so that the fisherman's soul can rest in peace. (Yamaguchi, 2010: 77 - author's translation)

These stories of reincarnation appear reminiscent of the medieval tales in Nihon Ryōiki (787824 ? CE), which were compiled in order to publicise Buddhist ideas. A variety of stories in the volumes depict the karmic cycle as the principle of cosmic order and specify that one should not abuse an animal since the action could precipitate bad karma. In this karmic cosmology, the realms of human and ningyo form a continuum, the modus operandi of which generates recurrent stories of reincarnation ${ }^{7}$. In these, the ningyo is often represented as becoming human in a certain stage of its life or as the result of its life history. The tales generate a mythical reality of karmic assemblage between the ningyo and human not simply to explain why the ningyo exists but also because they contain the very desire to form the cosmos. Therefore, while the reality of tales concerning the Biwako ningyo and their mummification are essentially mythical; assumptions of their veracity are essential for the temples that store them. Retained stories thereby authenticate the identities of the mummies. By virtue of being retold and printed in leaflets and websites they have become part of the substance of reality of Biwako.

Interestingly, a number of tales concerning ningyo no miira are reminiscent of Levi-Strauss's analytical typology in Le Cru et Le Cuit ${ }^{8}$ (1964); and the karmic legends concerning ningyo no miira can be expressed through the following structural model:

\footnotetext{
${ }^{6}$ A multiply armed Buddhist statue representing mercy.

${ }^{7}$ Although no tales about ningyo appear in the Nihon Ryoiki, it often relates tales about paranormal creatures as the "fruit" of bad karma. A tale concerning a greedy landlady, for instance, recounts that seven days after her funeral she emerged from her coffin with a torso of a cow (Nakada, 1980: 186-189).

${ }^{8}$ While this title is often translated as 'The Raw and the Cooked'; the term "prepared' is a more accurate translation of "cuit" and is more appropriate to the author's usage of the latter term.
}

\section{Shima Volume 12 Number 22018}




\title{
Le Cru ('The Raw') : Le Cuit ('The Prepared')
}

\author{
Ningyo : Water Natural Life : Mummification Land : Enshrinement
}

Ningyo had to be dried and mummified in order to preserve them and to crystallise a lasting material representation of the waters from whence they were perceived to originate. On the left of the diagram, the domain of natural life is allegorised by the live ningyo and the water. The centre shows the transition between the ningyo's natural state and mummification and the category on the right is the domain of culture, manifest in the enshrinement of the mummy in a temple. In this sense, the reliquaries around Biwako can be considered "power spots" where the elements of water and land exchange their substance in order to materialise the mummified ningyo. In this structuring process, the mythical reality surrounding Biwako generates the cultural memory of a tragic historical event: Prince Umayado is lamentably dead and the ningyo is slaughtered and mummified. By the same token, esoteric Buddhist cosmology encultures spiritual ways of life in the vicinity of the event: the ningyo transitions from being "raw" in the water and being mummified and enshrined (ie symbolically prepared), in a process entailing the interrelation of water, land and supernatural and human elements in a karmic cycle. This is akin to Kuyō, the Buddhist commemorative ritual that irreversibly shifts the karmic cycle from the raw to the prepared side in completing an enculturing process. The death of the ningyo, a half-fish and half-human, is an agency that connects the water-nature and land-human in transformation.

Structuralist analyses such as that advanced above do not pick up the essential aspect that only substance can materialise the legends. In other words, it is the very materiality of the ningyo no miira, in its interaction with the water and oral mythical history, that generates the reality in its own right. As for the ningyo and ningyo no miira, the legends concerning them render them the agents of Biwako since they attracted religious figures such as Prince Umayado and Kūkai to its shores. The mysterious ningyo mummies thereby became real in the geographical and historical space of the lake. As a consequence, Biwako becomes not only a geographical space but also exists as an event. This materialism of mythical reality is the reality of Biwako. The very substance of the mummified ningyo becomes the agent to the actuality of the water and to the materiality of religious structures. The ningyo no miira legends thereby manifest what Gell identified as the "intention" that influences reality and generates events. The pensé sauvage (to use Lévi-Strauss's [1962] expression) thereby gives substance to its mythical structures. In this regard-the legends being post factum and ignoring the order of historical events-historicity is generated by means of performances that include the enshrinement of ningyo no miira or the construction of other monuments associated with the spiritual aspect of the lake. The itineraries of mystery hunters, and perhaps the pilgrims of the past who have been inspired by the legends, generate an aquapelagic assemblage in the vicinity of enshrined ningyo. In this, the latter's "flesh" is in fact no different from Gell's boiled egg.

\section{Island Sanctuary}

Biwako contains four islands and a small number of rocky islets. Among the islands, only Okishima, off the south shore of the mid-part of the lake, and the bridged island of Yabasekihan, in the far south, are populated. Chikubushima and Takeshima (in the centre of the lake) have no residential areas but have religious structures maintained by priests and monks who commute from the shore each day. Although none of the island shrines house

\section{Shima Volume 12 Number 22018}


ningyo no miira artefacts, these island sanctuaries exemplify how enshrinement generates shimatic space. As in the case of Chikubushima (Figure 3), which exists, in totality, as an object of worship; religious structures interact as an agency by containing objects of intention, such as curios or sacred artefacts, that enable events to take place in their vicinities. ${ }^{9}$ In these island sanctuaries, sacred objects such as Shinto goshintai (physical objects in which spirits reside) and Buddhist honzon (the main, spiritually endowed object in a temple or domestic worship space) inculcate the existence of spiritual power and focus the subject of worship. ${ }^{10}$ Chikubushima's shimatic space manifests a concentric circle of worship since it enshrines a religious artefact in its core that is surrounded by sacred buildings, and, thereby, the island itself as an object of worship. The name of the island seems to be derived from the Shinto goddess Ichikishimahime, who was the guardian of sea lanes in the Genkai sea, off the southern coast of Kyushu, and is identified with Benzaiten (Suwa, 2016). In fact, Chikubushima represents both Buddhist and Shinto elements. The Hoggonji temple and the Tsukubusuma shrine are both located on the island, and the shrine (also known as Chikubushima-jinja), was once called Benzaiten-sha, since it enshrines the goddess Benzaiten. Here, the waters of Biwako interact as an agency for a Hindu-BuddhistShinto goddess who is associated with water, fishing, performing art, music, and prosperity. The aquapelago of Chikubushima is assembled by the enshrinements enacted upon it and Biwako's encircling waters render the island as spiritually significant.

It was not uncommon for a Shinto shrine to contain a Buddhist pavilion, belfry or temple before modernity. Such buildings were called bettoji ("concurrent temples") and were found throughout Japan until the two religions were officially separated when Shinto was specified as the national religion during the early Meiji era. The nationally organised bettoji acted as an administrative office for local shrines since Buddhist monks and disciples were allowed to travel between them (at a time when population movement within Japan was otherwise restricted). Thus, despite the presence of bettoji, the Shinto shrines conducted their own rituals. Behind the idea of bettöji is a religious ideology called honji suijaku, manifest in an iconography that aligns Shinto deities with Hindu-Buddhist devas. Since Shinto gods are invisible, its worshippers visualised their Buddhist counterparts as icons called honjibutsu. When a Shinto shrine was relocated due to separationist policies, these syncretic honjibutsu often remained in obscure spaces within Buddhist temples and new goshintai were made to be the body of the goddess.

The idea of a Shinto-Buddhist assemblage after honji suijaku is reflected in the Hōgonji temple's account of its origin in the medieval period. The temple was supposedly founded in $724 \mathrm{CE}$ after the Emperor Shōmu had a vivid dream in which Amaterasu stood by his pillow, telling him of an island in Biwako that was sacred to Benzaiten. The goddess also told him that his country would be blessed by peace and prosperity if he built a temple there dedicated to her. The Emperor immediately sent the monk Gyōki to Biwako to find an island build a reliquary and pavilion on it. The temple remained for many centuries until the state moved to convert Buddhist shrines into Shinto ones. In the case of Chikubushima, sustained resistance from dissenters led to a compromise whereby the main pavilion was allowed to continue as a shrine within a Shinto complex. The current main pavilion was built in 1937 to restore prominence to its worship of Benzaiten.

\footnotetext{
${ }^{9}$ Taikeijima has the lone Kentōji temple of the Nichiren Sect, which opened in 1655 . Since the whole island is considered as the goshintai, the body of the deity, there must have been some religious practices relating with honji suijaku before its establishment in its current form.

${ }^{10}$ By the same token, it is as if the life energy is felt in the ningyo no miira carefully stored in hinterland temples.
}

\author{
Shima Volume 12 Number 22018
}

-76 - 


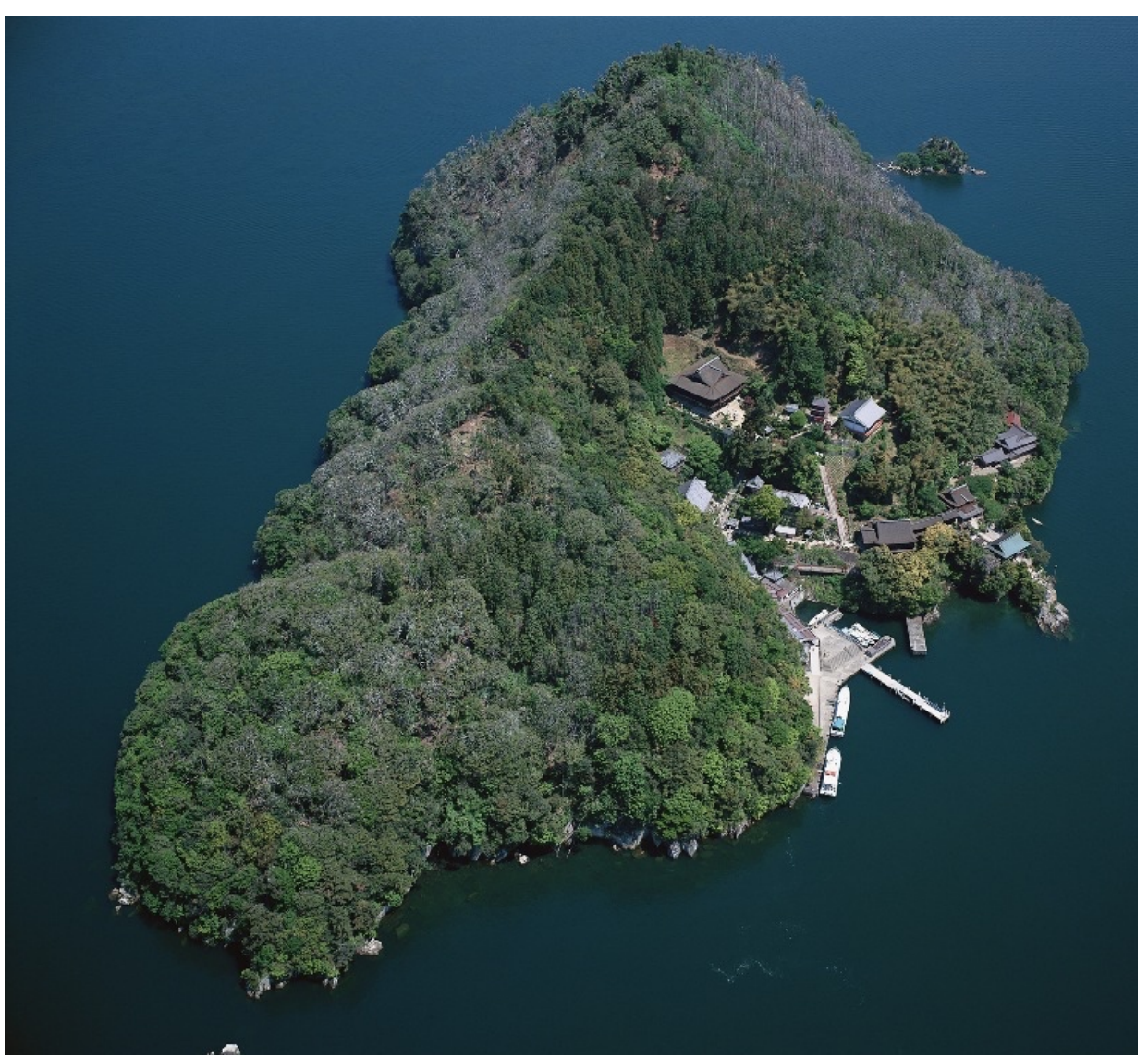

Figure 3 - Aerial shot of Chikubushima showing its jetty and complex of religious buildings (mid-left of image) (source: Go Biwako, 2014: online)

Gyōki (668-749) is a significant figure in the history sketched above. The monk and his colleagues and assistants undertook a number of civil engineering projects around Biwako, including the construction of bridges and roads, as part of their mission. A number of temples nationwide also claim Gyōki as their founder but many of these accounts are apocryphal. Despite this, myths concerning Gyōki distribute his personhood along the route of his legendary itinerary and his sainthood makes him an agent who contributes to the generation of Biwako's aquapelagic assembly. The territoriality of Gyōki's distributed personhood is manifest in the naming of medieval maps of the provinces of the Japanese archipelago as gyōkizu, which means "Gyōki's figure". The saint's body thereby becomes a fractal personhood in that his itinerary is projected in medieval cartography and forms a constellation of the ancient Japanese nation. In this regard, his body is also the agent of the Hōgonji monastery as well as the sanctuary of Chikubushima. Simultaneously, Gyōki's itinerant and nomadic agency created a cartography that territorialises the modus operandi of folk Buddhism through practice. The relationship between Chikubushima and Gyōki as agents suggests that the shimatic space of Biwako is generated by the distribution of personhood, (whether that of goddesses, princes or saints), in an animated itinerary. In

\section{Shima Volume 12 Number 22018}


addition, the networking of mythological material entities, such as religious buildings or sacred artefacts, is animated by means of orality that retains and retells legendary events and maintains related architecture and objects as embodiments of the mythical reality.

The previously discussed episode of Emperor Shōmu's dream reflects the idea of honji suijaku (the process through which Buddhist deities materialised in Japan through traditional spirit forms) in a particularly interactive manner. Rather than Amaterasu being a passive "patient" receiving a Buddhist deity, she is posed as an agent to/with Benzaiten. By extending her personhood to Benzaiten she enables other Shinto goddesses to be identified with Benzaiten (such as the island goddess Ichikishimahime and her sisters [Suwa, 2016]). But honji suijaku does not represent a mere iconography of hybridisation rather, it is an assemblage sui generis if it is experienced as a mythical reality that influences the makeup of what Gell called the "vicinity of events", in this case, the construction of the temple and shrine and therefore the naming, landscaping and cultural conduct in the locale. Chikubushima, which is the mythical reality of honji suijaku, has substance of the water and island. Honji suikaku, in this regard, is in tandem with substantive background: water or land. Consequently, an island becomes an aquapelagic assemblage in which a sacred spot constitutes itself as an attraction on account of periodic rituals and a traffic of visitors.

In addition to the above, both Buddhist temples and Shinto shrines are structured as containers of sacred artefacts known as honzon and goshintai. The former is an icon of deva or Buddha, and the latter is an enshrined body of a sacred spirit that is kept hidden from the public eye. These sacred bodies become the core for fractal shima-spacing, becoming agents to the sacred whose personhood is distributed. In this process, the distributed personhood involving sacred agents can be considered an "animation" since the action of seeing, including the inaction of not being able to be seen, operates among those who share a sensibility for the sacred. In the case of temples and shrines, the fractal process of distributed personhood can involve collection, as in the case of ningyo no miira folklore. It is likely that the ningyo no miira were not initially fabricated with any religious intent. Despite this, legends concerning folkloric ningyo provided the pretext for their subsequent enshrinement as they were collected and stored in religious facilities. In this process, the personhood of the prince (Umayado) and saint (Kukai) were drawn even deeper into the assemblage and the core of the fractal acquired an even greater density of signification. The animation of territoriality, by an assemblage of orality and substance, is key to the space of shima as it is enacted in cultural imagination. Needless to say, the relationship between the two is not one between signifier and signified. since orality and substance simply overlap or envelop with each other as an assemblage, and they never assume clear divisions of function of signification like a sign or a symbol.

The connections between the ningyo, the lake and the island are further suggested by other folkloric tales. In Ayama, in Mie Prefecture, for instance, there is a story concerning a temple that housed a wooden statue of a ningyo. The statue was believed to represent a ningyo that once lived in Biwako and it was perceived to have the power to generate rain if prayed to (Hotta, 1978). This tale illustrates the manner in which waters interact as an agent for the ningyo to generate reality in form of rainmaking. Acquiring the power to generate rain, the statue and its referent ningyo became associated with Benzaiten. In this tale of transfiguration, the mimesis of the ningyo with Benzaiten, it is the water that interacts as agent. The Biwako waters, as consequence, no longer assume the passive role that Gell refers to as a "patient" (1998) but generate a web of intention that animates sociocultural interactions. This web is multifaceted, since layers of personhood, the ningyo, Benzaiten etc.,

Shima Volume 12 Number 22018

-78 - 
are involved. While the sacred artefact involved can be identified as neither a honzon nor a goshintai, its perceived power allowed it to operate as a subject of worship.

\section{Conclusion}

The phenomena discussed above exemplify that fractal personhood is key to the territorialisation of shimatic space. This particular assemblage, derived from the aquapelagic imaginary, particularly involving ningyo and islands, materialises as a refrain between water and land. The fractal personhood that is distributed in the vicinity of events can be multifaceted as the aquapelagic imaginary of honji suijaku interacts. In a larger sense, the Japanese archipelago and its surrounding seas, the inland waters, the islands on the inland waters and the sanctuaries within them, collectively constitute a rhythmic refrain between water and land. In fact, with regard to lakes, the limnology of fractal features is effectual. For example, the sanctuary of substantive artefacts, including the ningyo no miira, is only activated when the myths of waters are related and when the myths are enacted. The mythicised artefacts are carefully stored and maintained in containers, buildings and estates and, in this process, a fractal structure that is animated as territorial interactions-and as an aquapelagic assemblage-becomes experience and sensibility. The networking of representable beliefs and substantive materiality interacts as if a diagrammatic landscape of the lake area connected by its water systems. The livelihood in Biwako is animated when a mummy or a goddess becomes the core of the fractal, which interacts as distribution of personhood. The communities and sacred places connect visitors and, as a consequence, nomadic movements of sacred objects, including ningyo no miira, become delineated as systems of mythical reality. Shinto goddesses, emperors, princes, saints as well as ningyo revived through relics generate the reality that is animated in fractal structure, as the entire assemblage of waters is a becoming of intentions and desires. In this assemblage of watermyth-reality, Shinto, Buddhism or the folklore of mummies are inseparable and indispensable for each other.

In addition, the territoriality of Biwako ningyo no miira and islands cannot be a matter of occupancy or possession. Rather, it is a particular type of spatial arrangement- the commons of kami (Akimichi, 2004) - that animates the territory. Kami is a Japanese word meaning a god, a demon, or any other supernatural and sacred being. In most cases they are unseen but dwell in artefacts. Such artefacts can be a goshintai to be boxed and sealed to be unseen but also a kami can take the form of an area of land, a rock, an island or mountain. In some other cases, the spirit can live in artefacts. The sacred in Japan can change its dimension freely as if generating a fractal. Any object belonging to kami can be the substance of goshintai, the body of the sacred, and therefore it must be maintained intact as well as unpolluted. In this regard, because the kami's authenticity is unchallengeable, the body of kami can generate the commons, where its ownership is "exclusive" (belonging solely to kami) and access to its resource is "non-competitive" (regulated solely by kami) (Akimichi, 2004: 219-222; Tisdell, 1999). The idea of the commons of kami can be extended to Biwako's territoriality by involving the sacred. It has exclusive ownership because the sacred space is absolutely possessed by the spirit, and its resource and property is protected, as exemplified in the case of Okinoshima, in Fukuoka prefecture, where not even simplest material object can be taken away.

The space of shima shares an affinity with the commons of kami and, in some cases, might appear as identical. A sacred core distributes personhood and allows the commons to develop into the space of shima. The sacred core also attracts mysterious personhoods, such

Shima Volume 12 Number 22018 
as ningyo no miira, and continues to substantiate mythical reality by keeping them as treasure. The aquapelagic assemblage-the substance of shimatic spacing-is generated from and interacted by the networking of sacred substances. The waters become an agent that extends through the networking, as the shima that surrounds them is territorialised in the names of princes, saints, gods and ill-fated ningyo from the aquapelagic imaginary. This relates to the fact that the animation generated by the repetition and rhythm of myths, the travelling of distributed personhoods and the power of orality, provides the indispensable condition for making mythical substance as "real" in the material plane. An island is an event in which rhythmic repetition forms substance. The space of shima therefore has to be considered and the dimension of time plays a decisive role in maintaining the commons of kami.

Thanks to Phillip Hayward for his insightful comments and editorial work on this article.

\title{
BIBLIOGRAPHY
}

Akimichi, T (2004) Komonzu no Jinruigaku, Tokyo: Jinbunshoin

Benjamin, W (1979) 'On the Mimetic Faculties', Reflections (Demetz, P [ed], translated by Jephcott, E), New York: Dover

Chikubushima Hōgonji (nd) 'Hōgonji History': http://www.chikubushima.jp/origin accessed 25th April 2018

Frazer, J (1976 [1911]) The Golden Bough, London: Macmillan

Go Biwako (2014) 'Chikubu Island (Chikubushima): http://en.biwakovisitors.jp/gobiwako/explore/chikubu-island-chikubushima/ - accessed 14th August 2018

Gell, A (1998) Art and Agency, Oxford: Oxford University Press

Hashimoto, M (2012) 'Medieval social Relationships and Lake Biwa Fisheries' in Kawanabe, H, Nishino, M and Maehata M (eds) Lake Biwa: Interactions between Nature and People, Dordrecht, London and New York: Springer: 269-274

Hayward, P (2012) 'Aquapelagos and Aquapelagic Assemblages', Shima v6nı: 1-11

----- (2017) Making a Splash: Mermaids (and Mermen) in 2oth and 21st Century Audiovisual Media, New Barnet: John Libbey and Co./University of Indiana Press

(ed) (2018) Scaled for Success: The Internationalisation of the Mermaid, New Barnet: John Libbey and Co./University of Indiana Press

Hotta, Y (1978) 'Ningyo Zakkō', Fokuroa v39 n4o: 1-30

Igarashi M (2017) 'Biwako ni Ningyo?': https://bqspot.com/kansai/shiga/9311 - accessed April 25th 2018

\author{
Shima Volume 12 Number 22018 \\ -80 -
}


Kannonshōji (n.d) 'Kannonshōji Engi': http://www.kannon.or.jp/omen/ - accessed 25th April 2018

Kawanabe, H, Nishino, M and Maehata M (eds) Lake Biwa: Interactions between Nature and People, Dordrecht, London and New York: Springer

Levi-Strauss, C (1962) La Pensée sauvage, Paris: Librairie Plon

----- (1964) Le Cru et le Cuit, Paris: Librairie Plon

Nihon Denshō Taikan Seisaku Īnkai (2017) 'Shiga', Nihon Denshō Taikan:

http://www.japanmystery.com/siga/siga_top.html - accessed 25th April 2018

Nippon Kichi (2008) 'Shiga Ganjou-ji / Ganjoji Temple', Nippon Kichi February 18th: https://nippon-kichi.jp/article_list.do?kwd=995\&ml_lang=en 8 - accessed July $13^{\text {th }} 2018$

Nihon Ryōiki (787-824? CE) - English language version translated and edited by Nakamura, K.M (1973) as Miraculous Stories from the Japanese Buddhist Tradition: the Nihon ryōiki of the monk Kyokai, Princeton: Harvard University Press

Sōtōsōmuchō (2018) Sōtōzen Navi: sotozen-navi.com/ - accessed 27th April 2018

Suwa J (2007) 'The Space of Shima', Shima vı nı: 6-14

----- 'Shima and Aquapelagic Assemblages: A Commentary from Japan', Shima v6 nı: 12-16

----- (2017) 'Becoming Island: The Aquapelagic Assemblage of Bentensai Festivals on Sakurajima, in Sai Village, northern Japan', Shima vı n2:5-19

Taussig, M (1993) Mimesis and Alterity, New York: Routledge

Tisdell, C (1999) 'Economic, Ecology and Sustainable Agricultural Production', in Dragun, A and Tisdell, C (eds) Sustainable Agriculture and Environment, Cheltenham: Edward Elgar: $37-56$

Yamaguchi, N (2010) Ketteiban Yōkai Mīra Kanzen File, Tokyo: Gakushu Kenkyu Sha 